Article

\title{
Sustainable synthesis of ammonium nickel molybdate for hydrodesulfurization of dibenzothiophene
}

\author{
Huan Liu a,b, Changlong Yin a , Hongyu Zhang a, Chenguang Liu a,* \\ a State Key Laboratory of Heavy Oil Processing and Key Laboratory of Catalysis of CNPC, China University of Petroleum (East China), Qingdao 266580, \\ Shandong, China \\ b State Key Laboratory of Safety and Control for Chemicals, Sinopec Safety Engineering Institute, Qingdao 266071, Shandong, China
}

\section{A R T I C L E I N F O}

\section{Article history:}

Received 30 March 2016

Accepted 6 May 2016

Published 5 September 2016

\section{Keywords:}

Hydrodesulfurization

Solid-state reaction

Water-assisted grinding

Ammonium nickel molybdate

Unsupported catalyst

\begin{abstract}
A B S T R A C T
This paper reports a sustainable, water-assisted, solid-state method for synthesizing ammonium nickel molybdate $\left(\left(\mathrm{NH}_{4}\right) \mathrm{HNi}_{2}(\mathrm{OH})_{2}\left(\mathrm{MoO}_{4}\right)_{2}\right.$, ANM), a precursor for an unsupported hydrodesulfurization (HDS) catalyst. The associated ANM formation mechanism is also discussed. The synthesis route consists of physical mixing of the raw materials, water-assisted grinding and heating. The formation mechanism involves replacement of a Mo atom by a $\mathrm{Ni}$ atom, generating the metastable intermediate $\left(\mathrm{NH}_{4}\right)_{4}\left(\mathrm{NiH}_{6} \mathrm{Mo}_{6} \mathrm{O}_{24}\right) \cdot 5 \mathrm{H}_{2} \mathrm{O}$. Heating of this intermediate at $120{ }^{\circ} \mathrm{C}$ removes the added water and produces ANM. Catalysts prepared by this method exhibit almost the same physicochemical properties and catalytic performance during the HDS of dibenzothiophene as materials made from ANM synthesized by a chemical precipitation procedure. Compared with traditional hydrothermal or chemical precipitation methods, this water-assisted, solid-state synthesis provides several significant advantages, including simplifying the synthetic procedure, reducing waste and energy costs and increasing product yields. These features will be highly important with regard to allowing the application of ANM in industrial-scale processes involving HDS reactions. This water-assisted, solid-state strategy can also be extended to the synthesis of isomorphous compounds such as ammonium cobalt (zinc and copper) molybdate.
\end{abstract}

(C) 2016, Dalian Institute of Chemical Physics, Chinese Academy of Sciences. Published by Elsevier B.V. All rights reserved.

\section{Introduction}

Owing to increasing environmental concerns and stringent regulations, hydrodesulfurization (HDS) has become an important process for the catalytic removal of heteroatom-containing compounds from petroleum [1]. HDS catalysts are regarded as the core of the hydrotreating process, and are primarily composed of molybdenum and/or tungsten sulfides enhanced with nickel or cobalt sulfides and dispersed on alumina $[2,3]$. When the sulfur content in the HDS product must be ultra-low (less than $10-15 \mu \mathrm{g} / \mathrm{g}$ ), it is necessary to remove highly refractory sulfur-containing compounds such as 4-methyl-dibenzothiophene and 4,6-dimethyl-dibenzothiophene $[4,5]$. In such cases, enhanced hydrogenation activity is required, because pre-hydrogenation of the aromatic ring often proceeds sulfur removal $[1,4,5]$. However, it is quite difficult for traditional supported HDS catalysts to achieve this goal due to their limited hydrogenation ability. For this reason, unsupported HDS catalysts have been synthesized and have exhibited unprecedented activity and have thus attracted increasing attention. As an example, the unsupported catalyst NEBULA can produce ultra-low sulfur diesel (less than $10 \mu \mathrm{g} / \mathrm{g} \mathrm{S}$ ) when em-

\footnotetext{
* Corresponding author. Tel/Fax: +86-532-86981716; E-mail: cgliu@upc.edu.cn

This work was supported by the National Natural Science Fundation of China (U1162203, 21106185) and the Fundamental Research Funds for the Central Universities (15CX02023A, 15CX06051A). Financial support from PetroChina Corporation Limited was also greatly appreciated. DOI: 10.1016/S1872-2067(16)62453-1 | http://www.sciencedirect.com/science/journal/18722067 | Chin. J. Catal., Vol. 37, No. 9, September 2016
} 
ployed in processing units originally designed to generate 350-500 $\mu \mathrm{g} / \mathrm{g}$ sulfur-containing diesel [6-8].

Previous results have shown that ammonium nickel molybdate $\left(\left(\mathrm{NH}_{4}\right) \mathrm{HNi}_{2}(\mathrm{OH})_{2}\left(\mathrm{MoO}_{4}\right)_{2}\right.$, ANM), which is composed of tetrahedral molybdate and octahedral nickel ions [9], is a good precursor for the preparation of highly-active unsupported HDS catalysts [3,10-13]. The unsupported HDS catalysts derived from ANM exhibit high catalytic activities towards sulfur and nitrogen compounds and poly-aromatics [3,10-13]. However, the methods available for the preparation of ANM are limited to chemical precipitation and hydrothermal reactions [3,9-13]. These techniques consume considerable quantities of water and precipitation agents and also generate large amounts of waste, thus leading to low yields of the desired product. To date, only Knyazheva et al. [14] has reported a solvent-free method, based on a mechanochemical process, for the preparation of ANM although, because of a lack of optimization, a mixture of various compounds was obtained. Therefore, before implementing ANM-based compounds in industrial processes, a green, sustainable synthesis method must be developed.

Inspired by the environmentally friendly synthesis of zeolites without added water or templates, as reported by Xiao's group [15-17], and by the exciting synthesis of metal-organic framework materials that have traditionally been prepared through hydrothermal reactions [18-20], we chose to examine green methods for the synthesis of ANM. After some trial-and-error, we developed a sustainable, water-assisted, solid-state strategy. The formation process, the physicochemical properties of the resulting ANM and the catalytic activity of this material during the HDS of dibenzothiophene (DBT) were all carefully investigated. The ANM synthesized by this facile water-assisted solid-state route shows comparable physicochemical properties (such as phase, pore properties and thermostability) and catalytic activities as ANM synthesized by a conventional chemical precipitation method.

\section{Experimental}

\subsection{Materials}

All the materials used in this work were purchased from the Sinopharm Chemical Reagent Co. (China), were analytical reagent grade, and were used without any further purification. Ammonium heptamolybdate $\left(\left(\mathrm{NH}_{4}\right)_{6} \mathrm{Mo}_{7} \mathrm{O}_{24} \cdot 4 \mathrm{H}_{2} \mathrm{O}, \mathrm{AHM}\right)$, basic nickel carbonate $\left(\mathrm{NiCO}_{3} \cdot 2 \mathrm{Ni}(\mathrm{OH})_{2} \cdot 4 \mathrm{H}_{2} \mathrm{O}, \mathrm{BNC}\right)$, basic cobalt carbonate $\left(2 \mathrm{CoCO}_{3} \cdot 3 \mathrm{Co}(\mathrm{OH})_{2} \cdot \mathrm{H}_{2} \mathrm{O}\right)$, basic zinc carbonate $\left(2 \mathrm{ZnCO}{ }_{3} \cdot 3 \mathrm{Zn}(\mathrm{OH})_{2}\right)$, basic copper carbonate $\left(\mathrm{CuCO}_{3} \cdot \mathrm{Cu}(\mathrm{OH})_{2}\right)$, nickel hydroxide $\left(\mathrm{Ni}(\mathrm{OH})_{2}\right)$, nickel nitrate $\left(\mathrm{Ni}\left(\mathrm{NO}_{3}\right)_{2} \cdot 6 \mathrm{H}_{2} \mathrm{O}\right)$, urea $\left(\mathrm{CO}\left(\mathrm{NH}_{2}\right)_{2}\right)$ and ammonium hydroxide $\left(28.8 \% \mathrm{NH}_{3}\right)$ were used for the synthesis of ANM and its isomorphous compounds. DBT $\left(\mathrm{C}_{12} \mathrm{H}_{8} \mathrm{~S}\right)$ and decalin were used for catalytic reactions.

\subsection{Water-assisted solid-state synthesis}

In a typical trial, $1.76 \mathrm{~g} \mathrm{AHM} \mathrm{(0.01} \mathrm{mol} \mathrm{Mo)} \mathrm{and} 1.25 \mathrm{~g} \mathrm{BNC}$ ( $0.01 \mathrm{~mol} \mathrm{Ni}$ ) were combined to obtain a Ni:Mo molar ratio of
1:1. These compounds were first physically mixed, then transferred to an agate mortar and ground for approximately $20 \mathrm{~min}$ while adding several drops of deionized water. Following this, each sample was placed in an oven at $120^{\circ} \mathrm{C}$ and heated for $12 \mathrm{~h}$ to obtain the final product.

CoMo, ZnMo and CuMo compounds were synthesized from the corresponding basic cobalt-, zinc- or copper carbonates, always maintaining a 1:1 Co ( $\mathrm{Zn}$ or $\mathrm{Cu})$ to Mo molar ratio. The synthesis steps were the same as described above when producing ANM.

A reference NiMo sample was also synthesized using a chemical precipitation method reported elsewhere [12,13]. In short, the appropriate amounts of nickel nitrate and AHM were first dissolved in deionized water to obtain a 1:1 Ni to Mo molar ratio. This solution was subsequently heated to $90{ }^{\circ} \mathrm{C}$ with magnetic stirring and ammonium hydroxide $\left(28.8 \% \mathrm{NH}_{3}\right)$ was added to the mixture in a dropwise manner to generate a green solid. Further addition of ammonium hydroxide caused the solid to redissolve and raised the $\mathrm{pH}$ of the solution to approximately 10.0 . The solution was then heated at $90{ }^{\circ} \mathrm{C}$ for 10 $\mathrm{h}$ while stirring. Finally, the resulting solid was isolated through vacuum filtration, washed several times with deionized water and dried for $12 \mathrm{~h}$ at $110{ }^{\circ} \mathrm{C}$. The ANM samples made via the facile water-assisted, solid-state reaction and by chemical precipitation are designated herein as ANM-SR and ANM-CP, respectively.

\subsection{Characterization}

The as-synthesized samples were characterized by X-ray diffraction (XRD), $\mathrm{N}_{2}$ adsorption-desorption, scanning electron microscopy (SEM), Fourier-transform infrared (FT-IR) spectroscopy, Raman spectroscopy, combined thermogravimetry and differential scanning calorimetry (TG-DSC), transmission electron microscopy (TEM) and X-ray photoelectron spectroscopy (XPS).

XRD characterizations were carried out with an X'Pert Pro MPD instrument (Panalytical) using $\mathrm{Cu} K_{\alpha}$ radiation. $\mathrm{N}_{2}$ adsorption-desorption trials were performed employing a ChemBET 3000 instrument (Quantachrome, USA) with nitrogen as the adsorption agent at $-196{ }^{\circ} \mathrm{C}$. Prior to characterization, each sample was heated at $350^{\circ} \mathrm{C}$ for $6 \mathrm{~h}$. Sample surface areas were obtained from the isotherms using the BET method. The total pore volumes were calculated by the BJH method and the BJH pore sizes were determined from the desorption branches of the isotherms. SEM observations were carried out using an FEI Quanta200 instrument with an accelerating voltage of $15.0 \mathrm{kV}$. Elemental analysis was carried out on an X-ray fluorescent instrument (Axios, Panalytical) under a high vacuum. FT-IR spectra were collected on a Nexus spectrometer (Nicolet, USA) using $\mathrm{KBr}$ disks and Raman spectra were acquired with a Thermo Fisher Scientific DXR microscope with a 532-nm excitation laser and the Omnic 8 software package. TG-DSC characterizations were performed under a high-purity $\mathrm{N}_{2}$ atmosphere at a heating rate of $10{ }^{\circ} \mathrm{C} / \mathrm{min}$. TEM observations were carried out with a JEM2100 microscope operating at $200 \mathrm{kV}$. STEM experiments together with elemental mapping were performed 
on a JEM-ARM200F instrument operating at $200 \mathrm{kV}$. XPS data were collected on a PHI5000 VersaProbe instrument and binding energies (BEs) were determined using the $\mathrm{C} 1 \mathrm{~s}$ peak (284.6 $\mathrm{eV}$ ) as a reference. Shirley background subtraction and Gaussian (20\%)-Lorentzian (80\%) decomposition parameters were applied when analyzing the spectra.

\subsection{Calculations}

The structures of AHM, ANM and an intermediate compound $\left(\left(\mathrm{NH}_{4}\right)_{4}\left(\mathrm{NiH}_{6} \mathrm{Mo}_{6} \mathrm{O}_{24}\right) \cdot 5 \mathrm{H}_{2} \mathrm{O}\right)$ detected in this work were simulated using the DMol3 module of the Material Studio 8.0 software package. When working with transition metal compounds, the m-GGA/Mo6-L functional was selected and the DNP/4.4 basis set was applied.

\subsection{Catalytic activity}

Unsupported HDS catalysts were prepared using ANM as a precursor and were sulfided in situ prior to the catalytic reaction $[12,13]$. The as-synthesized ANM-SR and ANM-CP were first tableted without any binder and then pulverized to a particle size of 20-40 mesh in preparation for the catalytic reactions. The HDS of DBT was carried out in a high pressure, down-flow, fixed bed reactor (10-mm i.d. and 400-mm length) $[12,13]$. In these trials, $0.10 \mathrm{~g}$ of an unsupported catalyst was diluted with quartz sand (20-40 mesh) to a total volume of 2.0 $\mathrm{mL}$ and then placed in the middle of the reactor. Before the reaction, the unsupported catalyst was pre-sulfided in situ at $330{ }^{\circ} \mathrm{C}$ for $12 \mathrm{~h}$ using a $3.0 \mathrm{wt} \% \mathrm{CS}_{2}$-decalin solution, under a hydrogen atmosphere. After sulfidation, the reactant (1.0 wt $\%$ DBT-decalin solution) was pumped into the reactor at a pressure of $2.0 \mathrm{MPa}$, applying a $\mathrm{H}_{2} /$ feed volume ratio of 750 , a weight hourly space velocity (WHSV) of $105.6 \mathrm{~h}^{-1}$ and a variety of temperatures between 240 to $320^{\circ} \mathrm{C}$. The liquid HDS prod- uct was analyzed by an Agilent 7820 gas chromatograph incorporating a flame ionization detector and a 50-m OV101 capillary column, coupled with a quadrupole mass spectrometer (GC-MS).

\section{Results and discussion}

\subsection{Electron microscopy results for ANM}

Electron microscopy images of ANM synthesized by the water-assisted solid-state method are presented in Fig. 1. The TEM micrograph (Fig. 1(a)) shows that the ANM had a quasi-spherical structure with particles approximately $700 \mathrm{~nm}$ in size, in accordance with the SEM results (Fig. 1(b)), in which particles with quasi-spherical morphologies are also seen, with sizes varying from 200 to $800 \mathrm{~nm}$. The STEM micrograph (Fig. $1(\mathrm{c})$, with $\mathrm{Ni}$, Mo and $\mathrm{O}$ elemental mapping in Fig. 1(d-f)) demonstrates that the $\mathrm{Ni}$, Mo and $\mathrm{O}$ atoms were in close contact in the ANM structure and were uniformly distributed.

\subsection{Investigation of the ANM formation mechanism}

The ANM formation mechanism was investigated with a combination of XRD, FT-IR and Raman techniques (Fig. 2). Fig. 2(a) exhibits peaks typically attributed to AHM (JCPDS 11-0071). The characteristic XRD peaks at $2 \theta=12.1^{\circ}, 17.4^{\circ}$, $23.5^{\circ}, 26.5^{\circ}$ and $29.6^{\circ}$ (Fig. 2(a)) confirmed the presence of highly crystalline ANM [3,9-12], indicating the successful synthesis of this compound by this facile and sustainable water-assisted, solid-state method. Fig. 2(a) clearly shows a highly crystalline phase transition from the raw materials to the ANM product. A metastable intermediate phase generating peaks at $8.0^{\circ}, 11.0^{\circ}, 15.3^{\circ}$ and $17.4^{\circ}$ was also detected, which is not observed in solvent-based reactions [3,9-12]. According to the JCPDS XRD database, this intermediate is $\left(\mathrm{NH}_{4}\right)_{4}\left(\mathrm{NiH}_{6} \mathrm{Mo}_{6} \mathrm{O}_{24}\right)$.
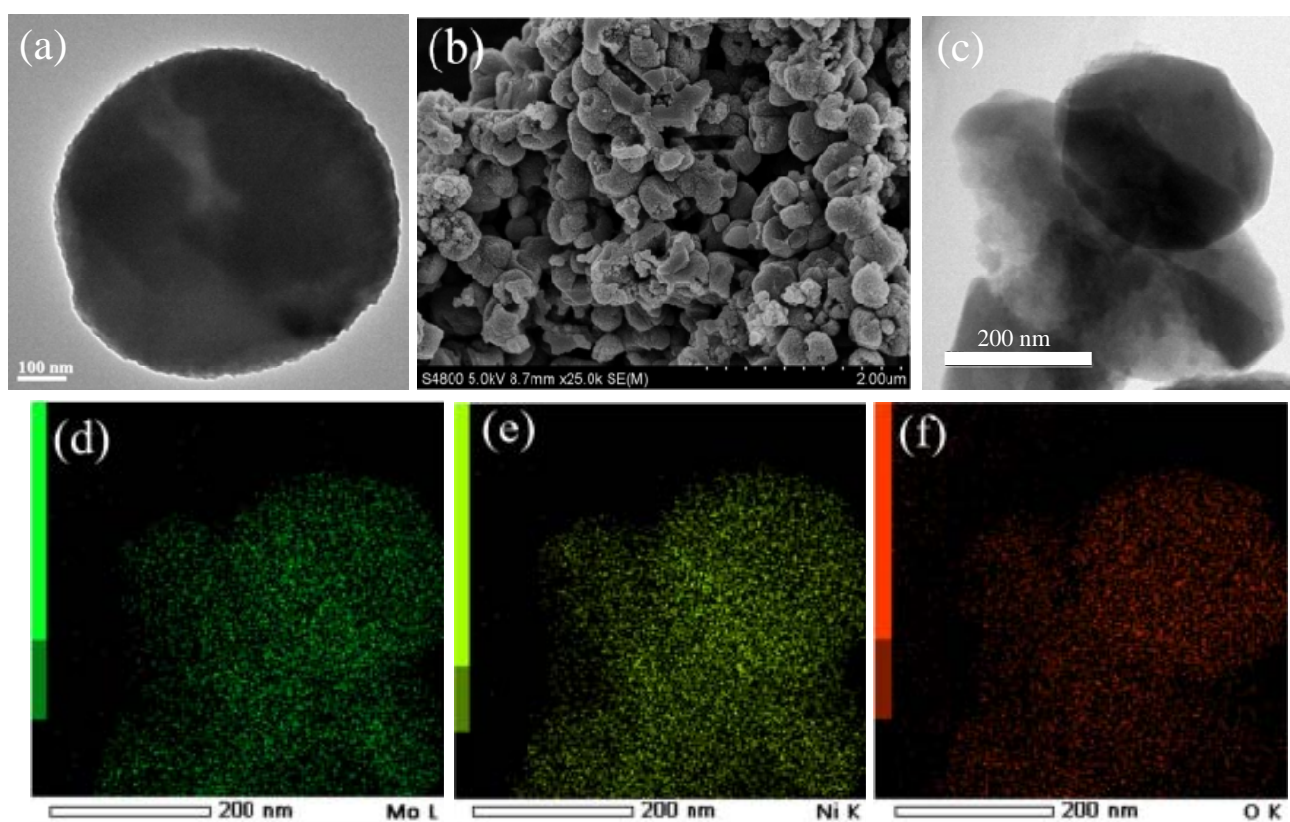

Fig. 1. TEM (a), SEM (b), STEM (c) micrographs, and mappings of Mo (d), Ni (e), O (f) elements of ANM synthesized by SR method. 

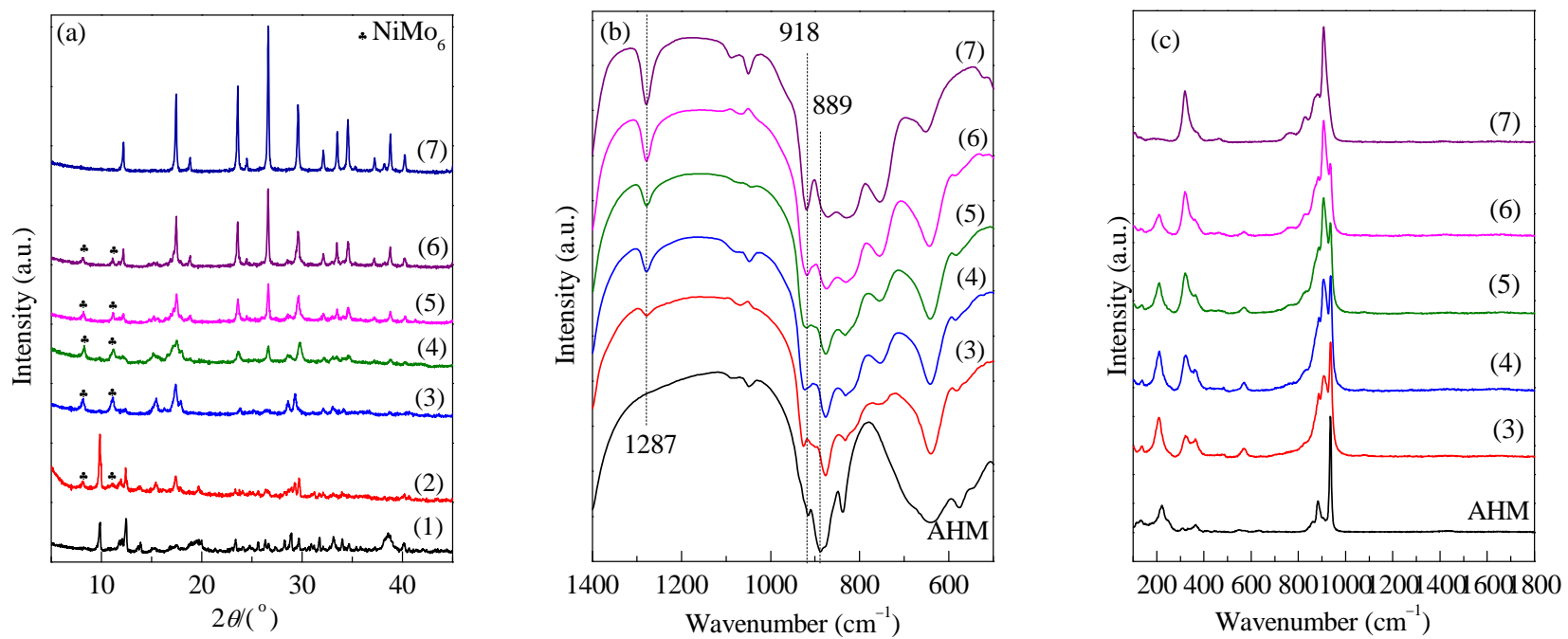

Fig. 2. XRD patterns (a), FT-IR spectra (b), and Raman spectra (c) of investigation formation mechanism. (1) Mixture of raw materials; (2) Adding water but not heat; Heated at $120^{\circ} \mathrm{C}$ for (3) $5 \mathrm{~min},(4) 15 \mathrm{~min}$, (5) $1 \mathrm{~h},(6) 4 \mathrm{~h}$, and (7) $12 \mathrm{~h}$.

$5 \mathrm{H}_{2} \mathrm{O}$ (JCPDS 22-0506, NiMo6) [21,22]. Evidently, simple physical mixing of the raw materials did not lead to $\mathrm{NiMo}_{6}$ formation, but this compound was formed following the addition of water (Fig. 2(a)). We believe that water promoted the migration of Ni-containing ionic species [23-27], leading to the replacement of Mo ions by $\mathrm{Ni}[27,28]$ and so promoting the formation of NiMo6. The water added during the synthesis also appears to have been completely removed during prolonged heating of the product. Eqs. (1) to (3) summarize the reactions involved in the synthesis process.

Formation of the $\mathrm{NiMo}_{6}$ intermediate:

$18\left(\mathrm{NH}_{4}\right)_{6}\left(\mathrm{Mo}_{7} \mathrm{O}_{24}\right) \cdot 4 \mathrm{H}_{2} \mathrm{O}+7 \mathrm{NiCO}_{3} \cdot 2 \mathrm{Ni}(\mathrm{OH})_{2} \cdot 4 \mathrm{H}_{2} \mathrm{O}+68 \mathrm{H}_{2} \mathrm{O}$ $\rightarrow 21\left(\mathrm{NH}_{4}\right)_{4}\left(\mathrm{NiH}_{6} \mathrm{Mo}_{6} \mathrm{O}_{24}\right) \cdot 5 \mathrm{H}_{2} \mathrm{O}+7 \mathrm{CO}_{2}+32 \mathrm{NH}_{3}$

Formation of the ANM product:

$3\left(\mathrm{NH}_{4}\right)_{4}\left(\mathrm{NiH}_{6} \mathrm{Mo}_{6} \mathrm{O}_{24}\right) \cdot 5 \mathrm{H}_{2} \mathrm{O}+5 \mathrm{NiCO}_{3} \cdot 2 \mathrm{Ni}(\mathrm{OH})_{2} \cdot 4 \mathrm{H}_{2} \mathrm{O} \rightarrow$ $9\left(\mathrm{NH}_{4}\right) \mathrm{HNi}_{2}(\mathrm{OH})_{2}\left(\mathrm{MoO}_{4}\right)_{2}+5 \mathrm{CO}_{2}+3 \mathrm{NH}_{3}+42 \mathrm{H}_{2} \mathrm{O}$

Overall equation for the water-assisted solid state reaction:

$6\left(\mathrm{NH}_{4}\right)_{6}\left(\mathrm{Mo}_{723} \mathrm{O}_{24}\right) \cdot 4 \mathrm{H}_{2} \mathrm{O}+14 \mathrm{NiCO}_{3} \cdot 2 \mathrm{Ni}(\mathrm{OH})_{2} \cdot 4 \mathrm{H}_{2} \mathrm{O} \rightarrow$

$21\left(\mathrm{NH}_{4}\right) \mathrm{HNi}_{2}(\mathrm{OH})_{2}\left(\mathrm{MoO}_{4}\right)_{2}+14 \mathrm{CO}_{2}+15 \mathrm{NH}_{3}+84 \mathrm{H}_{2} \mathrm{O}$

Following water-assisted grinding and subsequent heating at $120{ }^{\circ} \mathrm{C}$ for various time spans, a phase transformation from NiMo6 to ANM was detected (Fig. 2(a)). With increasing heating times (from 5 to $15 \mathrm{~min}$ ), the characteristic XRD peaks of ANM became more evident. Further increases in the reaction time enhanced the peak intensities of the ANM, while a small amount of NiMo6 was still detected. After heating at $120{ }^{\circ} \mathrm{C}$ for $12 \mathrm{~h}$, the XRD peaks attributed to the raw materials and to NiMo6 were no longer present, indicating that a pure ANM phase had formed. This is in agreement with the TG-DSC curves (Fig. 3), which also exhibit one main decomposition peak.

FT-IR spectra (Fig. 2(b)) provided more information regarding the ANM formation. When compared with the AHM spectrum, the ANM spectra exhibited new peaks at 918 and $1287 \mathrm{~cm}^{-1}$ that gradually increased in intensity with increasing heating duration, due to the vibrations of Mo-O bonds in the $\mathrm{MoO}_{4}{ }^{2-}$ structure [29] and of $\mathrm{Ni}-\mathrm{O}$ bonds [30], respectively. The peak at $889 \mathrm{~cm}^{-1}$ due to the Mo-O bond in AHM [29] was also shifted to $875 \mathrm{~cm}^{-1}$ in samples heated at $120^{\circ} \mathrm{C}$ for various time periods $[29,31]$, indicating changes in the nature of the Mo-O bond. The Raman spectrum of AHM (Fig. 2(c)) showed three main peaks, centered at 222, 883 and $936 \mathrm{~cm}^{-1}$, which is in good agreement with previous results [32]. After heating at 120 ${ }^{\circ} \mathrm{C}$ for $5 \mathrm{~min}$, new peaks appeared at 320 and $907 \mathrm{~cm}^{-1}$, attributed to the $v_{2}$ symmetric bend and $v_{1}$ symmetric stretching vibration of $\mathrm{MoO}_{4}{ }^{2-}$ [9], respectively. In addition, another peak at $570 \mathrm{~cm}^{-1}$ was generated, possibly due to NiMo6. With increasing heating time, the peaks attributed to AHM and NiMo6 gradually diminished in intensity, while peaks due to ANM simultaneously increased. After heating for $12 \mathrm{~h}$, no peaks due to AHM and $\mathrm{NiMo}_{6}$ could be detected. The ANM yields synthesized by this water-assisted, solid-state method and by the traditional chemical precipitation method were $98.8 \%$ and $90.2 \%$, respectively. This further confirms the superiority of the water-assisted, solid-state approach.

The Materials Studio software package was used to calculate the structures of AHM, NiMo6 and ANM (Fig. 4). AHM is composed of seven Mo atoms connected through $\mathrm{O}$ bridges (Fig. 4(a)), and ion replacement of a Mo atom by a Ni atom leads to the formation of NiMo6 [24,28], which has an Anderson-type structure (Fig. 4(b)) [22,33]. This replacement also changes the low-symmetry structure of AHM to the highly symmetrical NiMo6 structure [34]. Similar compounds, such as [Co$\left.\mathrm{Mo}_{6} \mathrm{O}_{24} \mathrm{H}_{6}\right]^{3-}$ [35], [ $\left.\mathrm{AlMo}_{6} \mathrm{O}_{24} \mathrm{H}_{6}\right]^{3-}[35]$ and $\left[\mathrm{CrMo}_{6} \mathrm{O}_{24}\right]^{9-}$ [34], have been synthesized, indicating that AHM can be easily substituted with heteroatoms. In our present work, we did not detect other intermediates, although we believe that, during the continuing reaction, some of the Mo cations remaining in the $\mathrm{NiMo}_{6}$ are replaced by $\mathrm{Ni}$ cations to give the final 1:1 Ni:Mo molar ratio in the ANM. The replaced Mo atoms are distributed in the form of $\mathrm{MoO}_{4}{ }^{2-}$ layers (Fig. 4(c)), while the Ni cations are coordinated by six $\mathrm{O}$ anions. These tetrahedral Mo layers and octahedral Ni layers form ANM. 

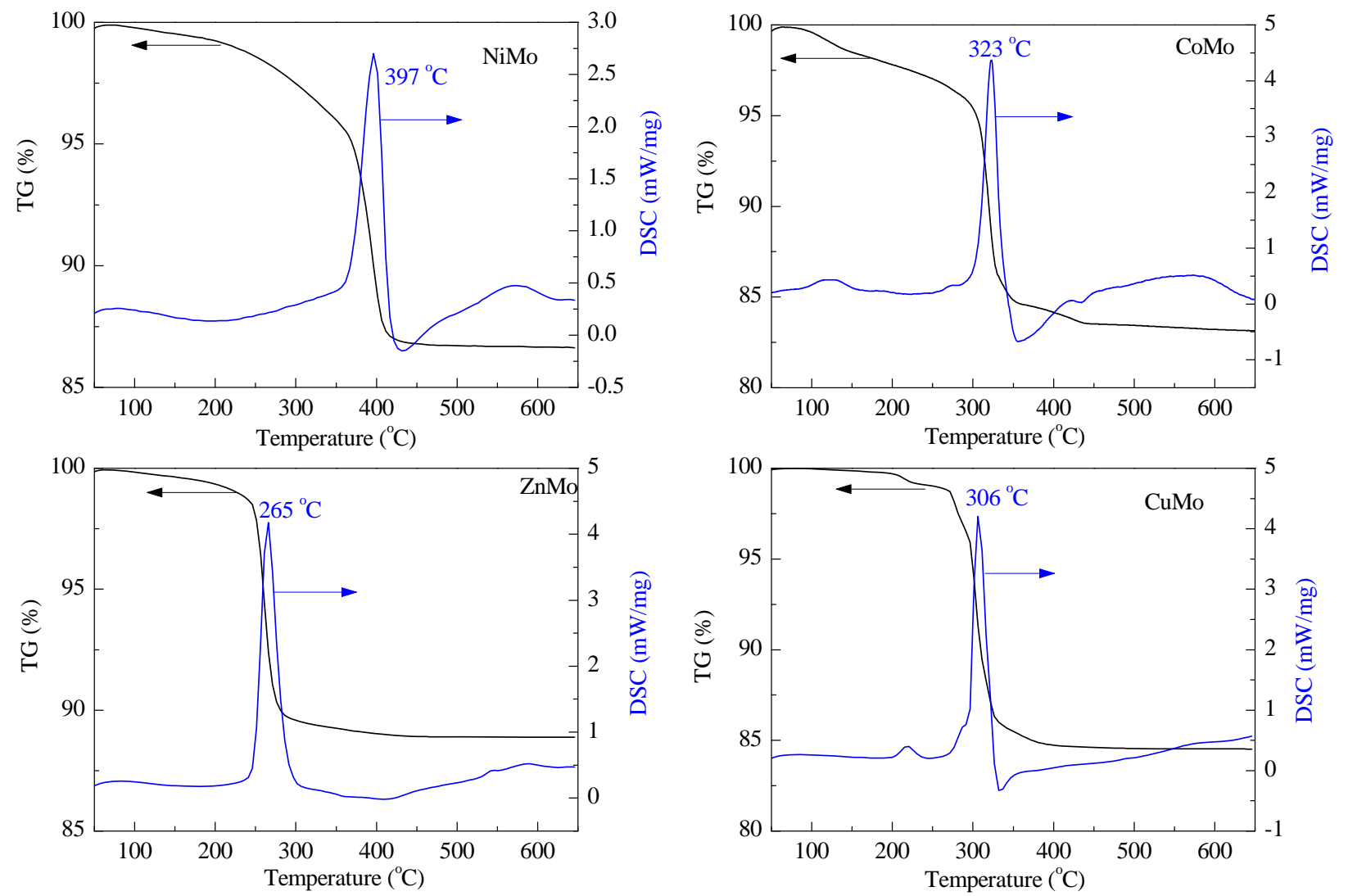

Fig. 3. TG-DSC curves of ammonium nickel (cobalt, zinc, and copper) molybdate.

(a)

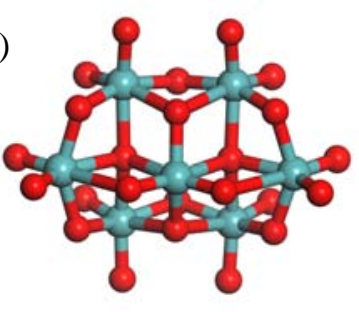

(b)

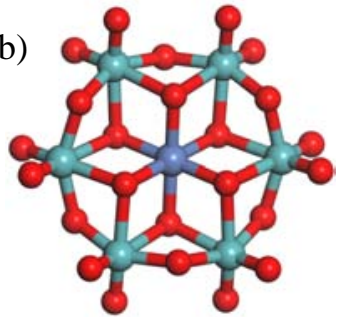

(c)

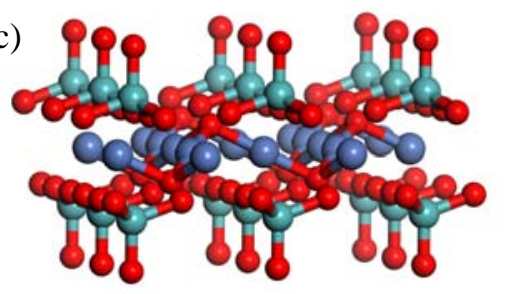

Fig. 4. Simulated structures of AHM (a), NiMo 6 (b), and ANM (c). Red-O; Violet-Ni; Cyan-Mo.

Based on the above, the formation mechanism of ANM can be described as follows. Initially, the physical mixing of AHM and BNC leads to the spontaneous dispersion of the BNC on the surface of the AHM. Without water addition, an undesired compound $\left(\left(\mathrm{NH}_{4}\right)_{8} \mathrm{Mo}_{10} \mathrm{O}_{34}\right)$ is generated, indicating that there is no obvious interaction between the AHM and BNC. Adding water serves to facilitate the mobility of Ni-containing species, promoting the ion replacement of Mo atoms by $\mathrm{Ni}$ atoms to form the intermediate NiMo6. Prolonged heating at $120{ }^{\circ} \mathrm{C}$ promotes the substitution of more Mo atoms by $\mathrm{Ni}$ atoms to give the final product, ANM. This process is illustrated in Scheme 1. Qualitative thermodynamic analysis can also provide some useful information concerning the formations of NiMo6 and ANM. As Eq. (1) shows, the reaction between AHM and BNC yields $\mathrm{NiMo}_{6}, \mathrm{CO}_{2}$ and ammonium. Since $\mathrm{AHM}, \mathrm{BNC}$ and NiMo6 are all solids, the release of both $\mathrm{CO}_{2}$ and ammonium should lead to a positive entropy change for the reaction $(\Delta S>$ 0 ). The reaction between AHM (a weak acid) and BNC (a weak

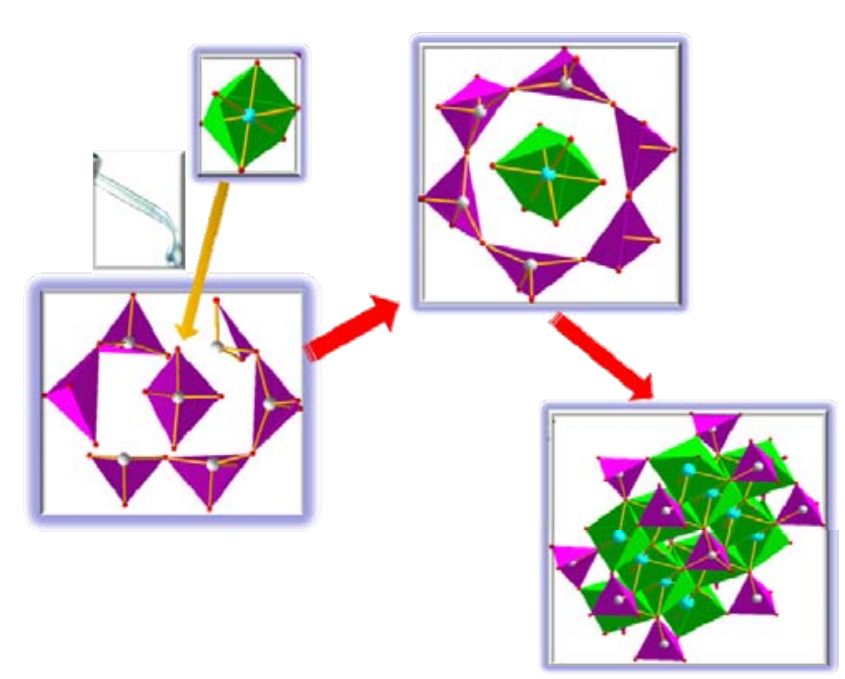

Scheme 1. Formation mechanism of ANM. 
base) is essentially a neutralization reaction, and so the enthalpy of the reaction is negative $(\Delta H<0)$. The negative enthalpy and positive entropy of the reaction between AHM and BNC contribute to a negative Gibbs reaction energy $(\Delta G=\Delta H-$ $T \Delta S<0$ ), such that the reaction is thermodynamically spontaneous. Eq. (2) indicates that the intermediate NiMo6 reacts with BNC to form the final product ANM at higher temperatures (such as $120^{\circ} \mathrm{C}$ ). This can be attributed to the weaker acidity of NiMo6 compared to AHM, which might lead to a reaction enthalpy approaching zero or possibly even higher than zero, in which case the entropy of the reaction would play a more important role. Because the entropy of the reaction in Equation (2) is also positive, increasing the reaction temperature decreases the Gibbs reaction energy, increasing the likelihood that this reaction will occur spontaneously.

\subsection{Water-assisted solid-state synthesis of ANM and its isomorphous compounds}

This facile and sustainable water-assisted, solid-state method could be extended to the synthesis of ammonium cobalt (copper, or zinc) molybdate. The XRD patterns, $\mathrm{N}_{2}$ isotherms and pore size distributions of the resulting NiMo, CoMo, CuMo and ZnMo compounds are presented in Fig. 5(a)-(c), respectively. Characteristic XRD peaks attributable to ANM and its isomorphous compounds are evident in Fig. 5(a), indicating the successful synthesis of the ammonium cobalt (copper, and zinc) molybdate $[9,12,13,36,37]$. In the case of the CuMo product, several other XRD peaks with lower intensities attributed to Mo-containing species, at $9.6^{\circ}, 11.6^{\circ}$ and $13.8^{\circ}$, were also generated. Owing to isomorphous replacement, $\mathrm{Ni}$ can be fully replaced by $\mathrm{Co}, \mathrm{Zn}$ or $\mathrm{Cu}[12,13,36,37]$, while retaining the original layered structure. After calcination at $350{ }^{\circ} \mathrm{C}$ for $6 \mathrm{~h}$, various $\mathrm{N}_{2}$ sorption isotherms were observed (Fig. 5(b)), ranging from an H4-type hysteresis loop for NiMo and CoMo to an H3-type for the CuMo and ZnMo products. Furthermore, the data in Fig. 3 and Table 1 show that the main decomposition temperature decreased from approximately $397^{\circ} \mathrm{C}$ for NiMo, to 323, 306 and $265^{\circ} \mathrm{C}$ for CoMo, CuMo and ZnMo, respectively.
Table 1

Pore properties, main decomposition temperatures and colors of the NiMo, CoMo, CuMo, and ZnMo materials.

\begin{tabular}{lccccc}
\hline Precursor & $\begin{array}{c}\mathrm{S}_{\mathrm{BET}} \\
\left(\mathrm{m}^{2} / \mathrm{g}\right)\end{array}$ & $\begin{array}{c}V_{\mathrm{P}} \\
\left(\mathrm{cm}^{3} / \mathrm{g}\right)\end{array}$ & $\begin{array}{c}\text { APD } \\
(\mathrm{nm})\end{array}$ & $\begin{array}{c}T_{\text {Decomposition }} \\
\left({ }^{\circ} \mathrm{C}\right)\end{array}$ & Color \\
\hline NiMo & 85 & 0.14 & 4.7 & 397 & Light yellow \\
CoMo & 49 & 0.11 & 5.9 & 323 & Pink \\
CuMo & 14 & 0.09 & 21.2 & 306 & Cyan \\
ZnMo & 13 & 0.09 & 24.0 & 265 & White \\
\hline
\end{tabular}

Therefore, the lower BET surface areas (Table 1) and wider pore size distributions (Fig. 5(c)) of the ZnMo and CuMo products are attributed to the decomposition and subsequent aggregation of the nanoparticles. Previous results for ANM synthesized by the chemical precipitation method $[13,36]$ showed a BET surface area of $88 \mathrm{~m}^{2} / \mathrm{g}$ and a type IV isotherm, and the ANM synthesized by this water-assisted, solid-state method had almost the same phase and pore properties.

Compared with the traditional hydrothermal or chemical precipitation methods for the synthesis of ANM [3,9-13,36], this water-assisted, solid-state strategy provides remarkable improvements. First, the synthesis procedure is greatly simplified, because it consists solely of physically mixing the reactants, water-assisted grinding and heating. The use of severe reaction conditions (high temperature and pressure), the separation of the precipitate from the solution, and time consuming drying procedures, which are all requirements of the hydrothermal and chemical precipitation methods, are successfully eliminated. Second, a high product yield can be obtained. Since only a small amount of water is added during this new process, the loss of products by dissolution is negligible. In contrast, the solvent-based reaction leads to some amounts of $\mathrm{Ni}$ - and Mo-containing compounds being dissolved, making the product difficult to fully recover. Third, in the water-assisted, solid-state reaction, almost no waste solution is produced, while the hydrothermal or chemical precipitation reactions generate $\mathrm{Ni}$ - and Mo-containing waste solutions in volumes much greater than that of the precipitated product. Fourth, significant reductions in the use of water, precipitating agents
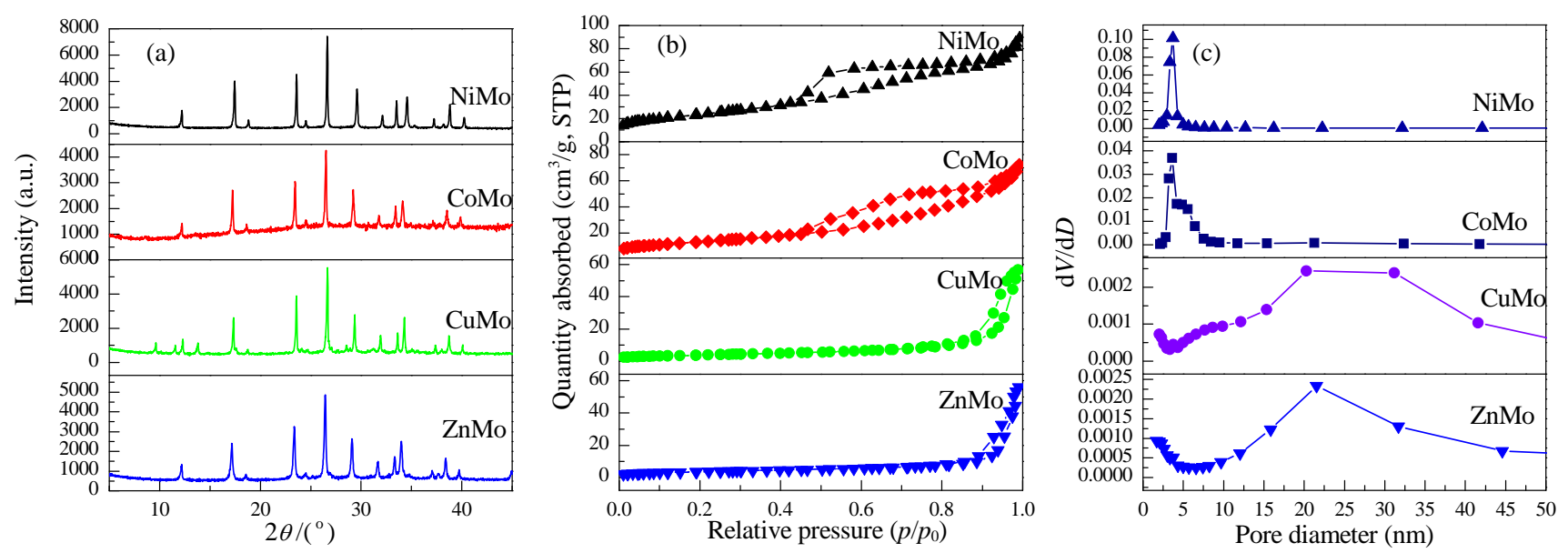

Fig. 5. XRD patterns (a), $\mathrm{N}_{2}$ adsorption-desorption isotherms (b), and pore size distributions (c) of ammonium nickel (or cobalt, copper, zinc) molybdate. 
and energy are achieved in this novel procedure. Last, this new method can potentially be extended to a broader range of processes, such as ion- and polymer-assisted syntheses [38], thus improving the physicochemical or catalytic properties of ANM-based compounds.

\subsection{Characterizations of sulfided catalysts}

The sulfided catalysts were characterized by XPS and HRTEM, and the results are presented in Fig. 6 and Tables 2 and 3. Different types of Mo-containing species have doublet XPS binding energies (BEs), due to the Mo $3 d_{5 / 2}$ and $3 d_{3 / 2}$ peaks and, in our analysis, we maintained the BE of the Mo $3 d_{3 / 2}$ peak $3.1 \mathrm{eV}$ higher than that of the Mo $3 d_{5 / 2}$ peak [39]. Owing to the various interactions with surrounding atoms, MoS2-based catalysts exhibit three different BEs [13,39]. The BE of the Mo $3 d_{5 / 2}$ peak at $228.8 \pm 0.2 \mathrm{eV}$ is attributed to molybdenum sulfide $\left(\mathrm{MoS}_{2}, \mathrm{Mo}^{\mathrm{IV}}\right)$, while the $230.0 \pm 0.2 \mathrm{eV}$ and $232.0 \pm 0.2 \mathrm{eV}$ BEs are ascribed to molybdenum oxysulfide $\left(\mathrm{MoO}_{x} \mathrm{~S}_{y}, \mathrm{MoV}^{\mathrm{V}}\right)$ and molybdenum oxide $\left(\mathrm{MoO}_{x}, \mathrm{Mol}^{\mathrm{VI}}\right)$. The peak in the vicinity of $226.0 \mathrm{eV}$ is ascribed to the $\mathrm{S} 2 \mathrm{~s}$ line and is also presented, together with the spectra of Mo $3 d$. Fig. 6(a) shows that no BEs associated with either molybdenum oxysulfide (Mov) or molybdenum oxide $\left(\mathrm{MoVI}^{\mathrm{VI}}\right.$ ) were present in the XPS patterns in the Mo $3 d$ region for either unsupported sulfided catalyst, indicating that the catalysts were in the sulfided state. This also confirms the complete sulfidation of the unsupported HDS catalysts synthesized by the water-assisted, solid-state and chemical precipitation methods.

The Ni $2 p$ XPS spectra are shown in Fig. 6(b). Previous results have demonstrated that there are several Ni-containing species $[13,39,40]$. The Ni $2 p$ peak with a BE of approximately
Table 2

XPS data of Mo $3 d$ and Ni $2 p$ of the sulfided catalysts.

\begin{tabular}{|c|c|c|c|c|}
\hline Method & $\mathrm{Mo}^{\mathrm{IV}} / \mathrm{MoTot}^{\mathrm{a}}$ & $\mathrm{Ni}^{0} / \mathrm{Ni}_{\text {Tot }}{ }^{\mathrm{b}}$ & NiMoS/Nitot & $\mathrm{Ni}^{2+} / \mathrm{Ni}_{\mathrm{Tot}}{ }^{\mathrm{b}}$ \\
\hline SR & 100.0 & 15.2 & 36.2 & 48.6 \\
\hline CP & 100.0 & 8.3 & 31.6 & 60.1 \\
\hline
\end{tabular}

Table 3

Average length and number of the stacking layers of $\mathrm{MoS}_{2}$ crystallites.

\begin{tabular}{lccc}
\hline Method & $L_{\text {aver. }}(\mathrm{nm})$ & $S_{\text {aver. }}$ & $f_{\text {Mo }}$ \\
\hline SR & 5.8 & 4.9 & 0.79 \\
CP & 6.7 & 5.6 & 0.85 \\
\hline
\end{tabular}

$852.3 \pm 0.2 \mathrm{eV}$ is due to metallic $\mathrm{Ni}$ species $\left(\mathrm{Ni}^{0}\right)$, while the $\mathrm{BE}$ of $\mathrm{Ni}$ in the NiMoS active phase appears around $853.7 \pm 0.2 \mathrm{eV}$ and the Ni $2 p$ peak at $856.0 \pm 0.2 \mathrm{eV}$ is primarily attributed to nickel oxide $\left(\mathrm{Ni}^{2+}\right)$. From Fig. 6 (b) it is evident that these XPS peaks were generated by sulfided catalysts with various levels of these species. The data in Table 2 show that higher concentrations of $\mathrm{Ni}^{0}$ and $\mathrm{NiMoS}$ active phases were present on the sulfided catalyst synthesized by the SR method than by the CP method.

The HRTEM micrographs of the sulfided catalysts are presented in Fig. 6(c). Characteristic slabs with an inter-planar distance of $0.62 \mathrm{~nm}$ are evident in both materials, a result that matches the typical (002) basal plane of $\mathrm{MoS}_{2}$ nanoparticles $[11,13,39]$. The slab lengths and stacking layers of the $\mathrm{MoS}_{2}$ crystallites were obtained by statistical analysis based on more than 20 micrographs and at least 300 slabs. The average length ( $\left.L_{\text {aver. }}\right)$ and average stacking $\left(S_{\text {aver. }}\right)$ were calculated according to the following equations.
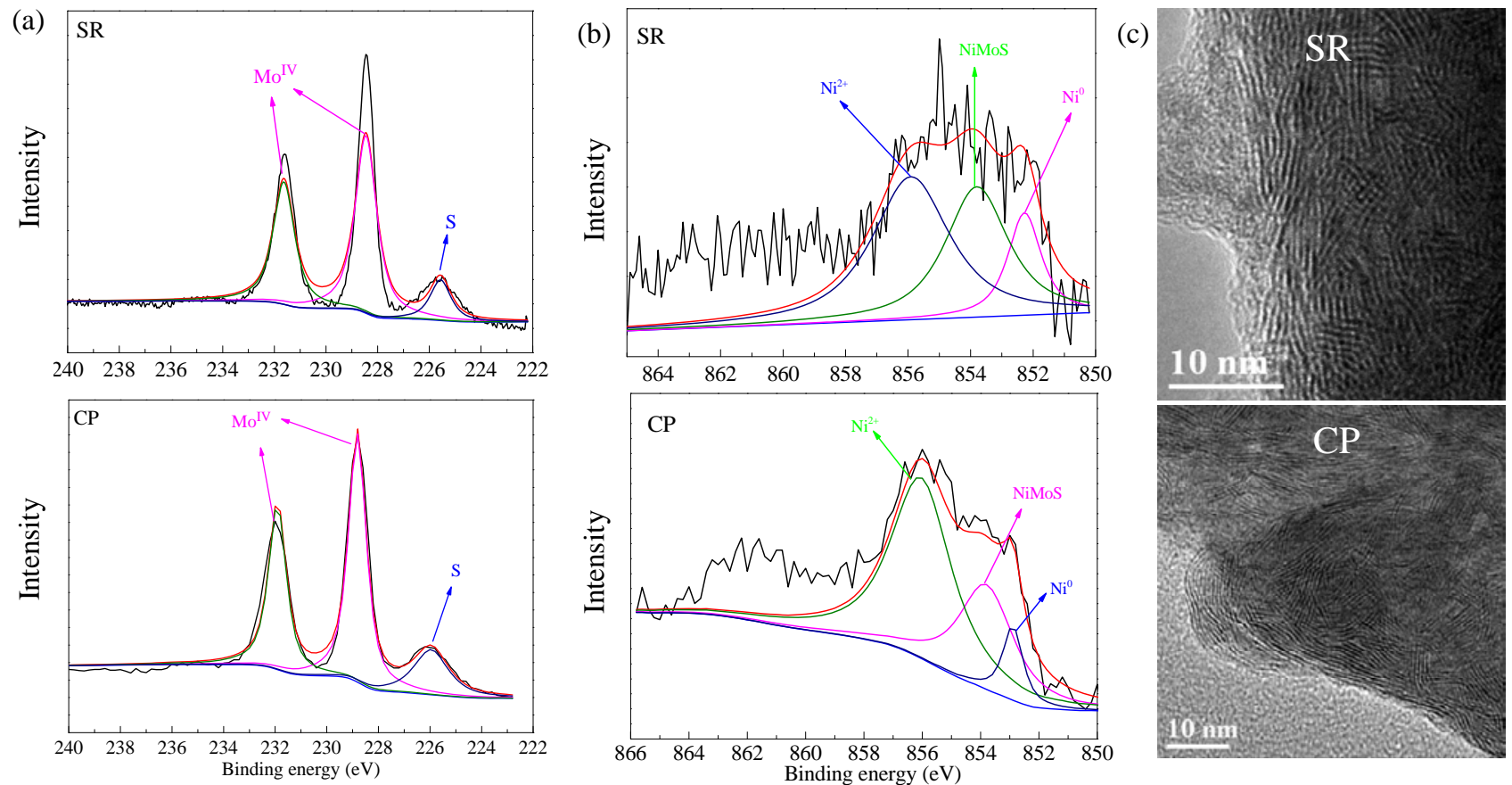

Fig. 6. XPS envelope of the Mo $3 d$ region (a), the Ni $2 p$ region (b) and HRTEM micrographs (c) of the sulfided catalysts synthesized by SR and CP method. 


$$
\begin{gathered}
L_{\text {aver. }}=\frac{\sum_{i=1}^{n} x_{i} L_{i}}{\sum_{i=1}^{n} x_{i}} \\
S_{\text {aver. }}=\frac{\sum_{i=1}^{n} y_{i} S_{i}}{\sum_{i=1}^{n} y_{i}}
\end{gathered}
$$

Here, $L_{i}$ is the length of a slab $i, S_{i}$ is the number of layers in a slab $i, x_{i}$ is the number of slabs within length $L_{i}$, and $y_{i}$ is the number of slabs with $S_{i}$ layers.

The following equation was employed to estimate the dispersion of $\mathrm{MoS}_{2}\left(f_{\mathrm{Mo}}\right)$.

$$
f_{\mathrm{Mo}}=\frac{\sum_{i=1}^{m}\left(6 n_{i}-6\right)}{\sum_{i=1}^{m}\left(3 n_{i}^{2}-3 n_{i}+1\right)}
$$

Here, $n_{i}$ is the number of Mo atoms along one edge of a MoS 2 slab, as calculated from its length $\left(L=3.2\left(2 n_{i}-1\right) \AA\right)$, and $m$ is the total number of slabs in the TEM micrographs. The calculated $L_{\text {aver, }} S_{\text {aver, }}$ and $f_{\text {Mo }}$ are summarized in Table 3.

The data in Table 3 demonstrate that the sulfided catalysts had significant average lengths and high $\mathrm{MoS}_{2}$ stacking numbers compared with traditional $\mathrm{Al}_{2} \mathrm{O}_{3}$-supported HDS catalysts [11]. As noted above, the sulfided catalysts were prepared by tableting the ANM precursor without any binder, followed by in situ sulfiding. Owing to the lack of a support, the $\mathrm{MoS}_{2}$ nanoparticles tended to agglomerate to form larger nanoparticles at high temperatures. The unsupported sulfided catalyst synthesized by the water-assisted, solid-state reaction exhibited a shorter average length and fewer stacking layers in the $\mathrm{MoS}_{2}$ nanoparticles, with values of $5.8 \mathrm{~nm}$ and 4.9 layers, respectively.

\subsection{Catalytic results}

Catalytic evaluations of the sulfided materials were performed in a fixed-bed reactor. DBT, a typical S-containing compound, was chosen as the model for the HDS reactions, and several products were detected and confirmed by GC-MS. As widely reported $[3,4,12,13,41]$, there are two main routes for the HDS of DBT. One route is termed direct desulfurization (DDS), in which the $\mathrm{S}$ atom of DBT is eliminated through a two-step reaction to produce biphenyl (BP) [41]. The other route is hydrogenation (HYD). In this route, DBT is first hydrogenated to form the intermediates tetrahydrodibenzothiophene (THDBT) and hexahydrodibenzothiophene (HHDBT), and the $\mathrm{S}$ atom is subsequently removed to yield cyclohexylbenzene (CHB). To estimate the selectivity for the two pathways, the following equations were employed.

$$
\begin{gathered}
\text { DDS }=\frac{\mathrm{BP} \times 100 \%}{\mathrm{THDBT}+\mathrm{HHDBT}+\mathrm{BP}+\mathrm{CHB}+\mathrm{BCH}} \\
\mathrm{HYD}=\frac{(\mathrm{THDBT}+\mathrm{HHDBT}+\mathrm{CHB}+\mathrm{BCH}) \times 100 \%}{\mathrm{THDBT}+\mathrm{HHDBT}+\mathrm{BP}+\mathrm{CHB}+\mathrm{BCH}}
\end{gathered}
$$

The DBT hydrodesulfurization turnover frequency values (TOF, $\mathrm{s}^{-1}$ ) were calculated according to the equation [42] below.

\begin{tabular}{|c|c|c|c|c|c|c|c|c|}
\hline & Conv. (\%) & THDBT & HHDBT & BP & CHB & $\mathrm{BCH}$ & HYD/DDS & $\begin{array}{c}\mathrm{TOF} \times 10^{4} \\
\left(\mathrm{~s}^{-1}\right)\end{array}$ \\
\hline SR & 93.8 & 0.6 & 0 & 1.9 & 3.2 & 0.5 & 2.3 & 28 \\
\hline CP & 94.0 & 0.7 & 0 & 2.0 & 3.1 & 0.2 & 2.0 & 26 \\
\hline
\end{tabular}

$$
\mathrm{TOF}=\frac{F \times x}{N_{\mathrm{Mo}} \times f_{\mathrm{Mo}}}
$$

Here, $F$ is the reactant molar flow $\left(\mathrm{mol} \mathrm{s}^{-1}\right), x$ is the conver-
Table 4

Catalytic reaction results of the sulfided catalysts at $240{ }^{\circ} \mathrm{C}$.

sion of DBT, and $N_{\text {Mo }}$ is the number of Mo atoms in the catalyst (mol).

The catalytic reaction results at $240{ }^{\circ} \mathrm{C}$ are reported in Table 4. Under moderate reaction conditions of a low reaction temperature of $240{ }^{\circ} \mathrm{C}$ and a high WHSV of $105.6 \mathrm{~h}^{-1}$, the hydrogenated intermediate HHDBT was not detected when using either unsupported catalyst, while other HDS products, including THDBT, BP, CHB and BCH were confirmed. The most abundant product was $\mathrm{CHB}$, produced via the HYD route. The second most abundant product was BP, which results from the DDS route. The HYD/DDS ratios of the HYD and DDS routes over the unsupported sulfided catalysts at $240{ }^{\circ} \mathrm{C}$ were 2.3 (SR) and 2.0 (CP), indicating that the sulfided catalysts exhibit significant hydrogenation abilities. This is beneficial in terms of producing ultra-low sulfur diesel, because refractory S-containing compounds and basic $\mathrm{N}$-containing compounds typically react solely via the HYD route $[1,4,5,13,41]$. The TOFs of the SR and CP catalysts were 28 and $26 \times 10^{-4} \mathrm{~s}^{-1}$, respectively.

The conversions of DBT at various temperatures (from 240 to $320^{\circ} \mathrm{C}$ ) over these two catalysts are shown in Fig. 7(a). Increasing the reaction temperature evidently enhanced the activities of the unsupported sulfided catalysts, such that the conversion of DBT increased from $6 \%$ at $240{ }^{\circ} \mathrm{C}$ to approximately $32 \%$ at $320{ }^{\circ} \mathrm{C}$. The product distributions obtained from these two materials are presented in Fig. 7(b) and (c). Upon raising the reaction temperature, remarkable increases in the production of BP and CHB over both were confirmed, while the levels of the intermediates THDBT and HHDBT remained low (less than 1\%). These results confirm that the unsupported catalyst derived from the facile and sustainable water-assisted, solid-state reaction had comparable catalytic properties, both in terms of activity and selectivity towards DBT conversion, to the catalyst derived from the traditional chemical precipitation method. This is chiefly attributed to the similar physicochemical properties of these two catalysts. There were no distinct differences in the $\mathrm{MoS}_{2}$ structure (considering $L_{\text {aver., }} S_{\text {aver. }}$ and $f_{\text {Mo }}$ ) between the sulfided catalysts synthesized using the SR and CP methods, and structure is typically understood to impact the active sites available for the HDS reaction $[12,41]$. The TOF values of the SR and CP catalysts at $240{ }^{\circ} \mathrm{C}$ were 28 and $26 \times 10^{-4} \mathrm{~s}^{-1}$, respectively, indicating that they behaved similarly during the HDS of DBT. Based on previous results $[3,12]$, additional enhancements of the unsupported HDS catalysts derived from the water-assisted, solid-state reaction might be obtained by optimizing certain subsequent steps, such as the calcination temperature and sulfidation conditions.

\section{Conclusions}

Highly crystalline ammonium nickel molybdate (ANM) was 

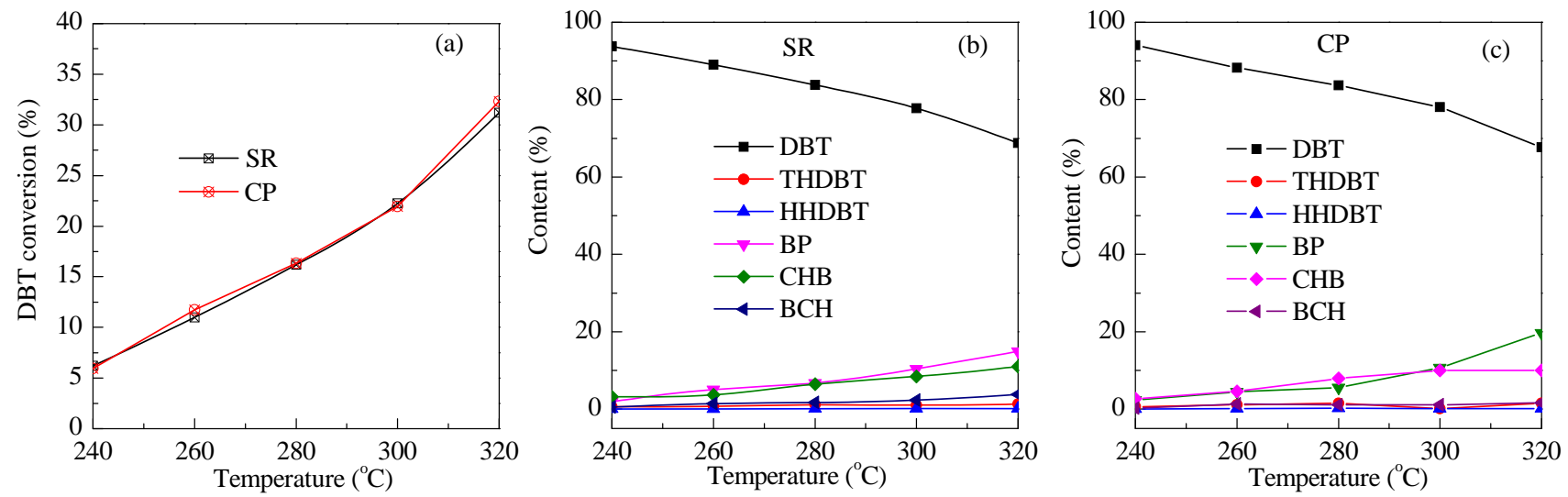

Fig. 7. Conversions of DBT (a), product distributions on the sulfided unsupported catalysts synthesized from SR (b) and CP (c) methods.

prepared in a sustainable manner with less pollutant generation and higher yield based on a water-assisted, solid-state synthesis route, and the associated formation mechanism was investigated. Ion replacement was found to play a significant role in the formation of the metastable intermediate $\left(\mathrm{NH}_{4}\right)_{4}\left(\mathrm{NiH}_{6} \mathrm{Mo}_{6} \mathrm{O}_{24}\right) \cdot 5 \mathrm{H}_{2} \mathrm{O}$, while heating at $120{ }^{\circ} \mathrm{C}$ led to more Mo atoms being replaced by $\mathrm{Ni}$ atoms, producing a 1:1 Ni:Mo molar ratio in the ANM. This water-assisted, solid-state strategy not only provides a green method for synthesizing ANM and its isomorphous compounds ammonium cobalt (zinc and copper) molybdate, but also enables a thorough understanding of the inorganic formation mechanism of these compounds. Catalytic results confirm that the unsupported sulfided catalysts synthesized by this sustainable route have catalytic properties comparable to those of material prepared by the traditional chemical precipitation method, both in terms of the conversion of DBT and the relevant product distributions. In relation to hydrothermal and chemical precipitation methods, this new water-assisted, solid-state strategy for synthesizing ANM has many advantages, including more efficient raw materials usage, better product yields, improved waste disposal and lower energy costs. This method thus represents a viable alternative to hydrothermal or chemical precipitation methods for industrial applications.

\section{References}

[1] T. D. Tang, L. Zhang, W. Q. Fu, Y. L. Ma, J. Xu, J. Jiang, G. Y. Fang, F. S. Xiao, J. Am. Chem. Soc., 2013, 135, 11437-11440.

[2] L. Hao, G. Xiong, L. P. Liu, H. Y. Long, F. Y. Jin, X. S. Wang, Chin. J. Catal., 2016, 37, 412-419.

[3] S. L. Amaya, G. Alonso-Núñez, T. A. Zepeda, S. Fuentes, A. Echavarría, Appl. Catal. B, 2014, 148-149, 221-230.

[4] Y. Y. Sun, R. Prins, Angew. Chem. Int. Ed., 2008, 47, 8478-8481.

[5] C. L. Yin, H. Liu, L. Y. Zhao, B. Liu, S. S. Xue, N. N. Shen, Y. Q. Liu, Y. P. Li, C. G. Liu, Catal. Today, 2016, 259, 409-416.

[6] F. L. Plantenga, R. Cerfontain, S. Eijsbouts, F.van Houtert, G. H. Anderson, S. Miseo, S. Soled, K. Riley, K. Fujita, Y. Inoue, Stud. Surf. Sci. Technol. Catal., 2003, 145, 407-410.

[7] S. Eijsbouts, S. W. Mayo, K. Fujita, Appl. Catal. A, 2007, 322, 58-66.

[8] Y. Gochi, C. Ornelas, F. Paraguay, S. Fuentes, L. Alvarez, J. L. Rico, G. Alonso-Núñez, Catal. Today, 2005, 107-108, 531-536.
[9] D. Levin, S. L. Soled, J. Y. Ying, Inorg. Chem., 1996, 35, 4191-4197.

[10] C. L. Yin, L. Y. Zhao, Z. J. Bai, H. Liu, Y. Q. Liu, C. G. Liu, Fuel, 2013, 107, 873-878.

[11] Y. E. Licea, S. L. Amaya, A. Echavarría, J. Bettini, J. G. Eon, L. A. Palacio, A. C. Faro, Catal. Sci. Technol., 2014, 4, 1227-1238.

[12] H. Liu, C. L. Yin, B. Liu, X. H. Li, Y. P. Li, Y. M. Chai, C. G. Liu, Energy Fuels, 2014, 28, 2429-2436.

[13] H. Liu, C. G. Liu, C. L. Yin, Y. M. Chai, Y. P. Li, D. D. Liu, B. Liu, X. H. Li, Y. Y. Wang, X. Z. Li, Appl. Catal. B, 2015, 174-175, 264-276.

[14] O. A. Knyazheva, O. N. Baklanova, A. V. Lavrenov, E. A. Buluchevskii, V. A. Drozdov, M. V. Trenikhin, N. N. Leont'eva, A. V. Vasilevich, V. A. Likholobov, Kinet. Catal., 2014, 55, 130-138.

[15] L. M. Ren, Q. M. Wu, C. G. Yang, L. F. Zhu, C. J. Li, P. L. Zhang, H. Y. Zhang, X. J. Meng, F. S. Xiao, J. Am. Chem. Soc., 2014, 134, 15173-15176.

[16] Q. M. Wu, X. Wang, G. D. Qi, Q. Guo, S. X. Pan, X. J. Meng, J. Xu, F. Deng, F. T. Fan, Z. C. Feng, C. Li, S. Maurer, U. Müller, F. S. Xiao, J. Am. Chem. Soc., 2014, 136, 4019-4025.

[17] Q. M. Wu, X. L. Liu, L. F. Zhu, L. H. Ding, P. Gao, X. Wang, S. X. Pan, C. Q. Bian, X. J. Meng, J. Xu, F. Deng, S. Maurer, U. Müller, F. S. Xiao, J. Am. Chem. Soc., 2015, 137, 1052-1055.

[18] T. Friščić, D. G. Reid, I. Halasz, R. S. Stein, R. E. Dinnebier, M. J. Duer, Angew. Chem. Int. Ed., 2010, 49, 712-715.

[19] W. B. Yuan, T. Friščić, D. Apperley, S. L. James, Angew. Chem. Int. Ed., 2010, 49, 3916-3919.

[20] M. Klimakow, P. Klobes, A. F. Thünemann, K. Rademann, F. Emmerling, Chem. Mater., 2010, 22, 5216-5221.

[21] O. A. Knyazheva, O. N. Baklanova, A. V. Lavrenov, V. A. Drozdov, N. N. Leont'eva, A. V. Vasilevich, A. V. Shilova, V. A. Likholobov, Kinet. Catal., 2014, 55, 121-129.

[22] U. Lee, H. C. Joo, J. S. Kwon, Acta Cryst. E, 2002, 58, i6-i8.

[23] G. A. Bowmaker, J. V. Hanna, R. D. Hart, B. W. Skelton, A. H. White, Dalton Trans., 2008, 5290-5292.

[24] T. Friščić, W. Jones, Cryst. Growth Des., 2009, 9, 1621-1637.

[25] E. Boldyreva, Chem. Soc. Rev., 2013, 42, 7719-7738.

[26] G. Kaupp, M. R. Naimi-Jamal, CrystEngComm, 2005, 7, 402-410.

[27] D. Braga, L. Maini, F. Grepioni, Chem. Soc. Rev., 2013, 42, 7638-7648.

[28] G. Rothenberg, A. P. Downie, C. L. Raston, J. L. Scott, J. Am. Chem. Soc., 2001, 123, 8701-8708.

[29] Y. D. Xu, Y. Y. Shu, S. T. Liu, J. S. Huang, X. X. Gao, Catal. Lett., 1995, $35,233-243$

[30] Ö. Yavuz, M. K. Ram, M. Aldissi, P. Poddar, S. Hariharan, J. Mater. Chem., 2005, 15, 810-817. 


\section{Graphical Abstract}

Chin. J. Catal., 2016, 37: 1502-1512 doi: 10.1016/S1872-2067(16)62453-1

Sustainable synthesis of ammonium nickel molybdate for hydrodesulfurization of dibenzothiophene

Huan Liu, Changlong Yin, Hongyu Zhang, Chenguang Liu*

China University of Petroleum (East China); Sinopec Safety Engineering Institute

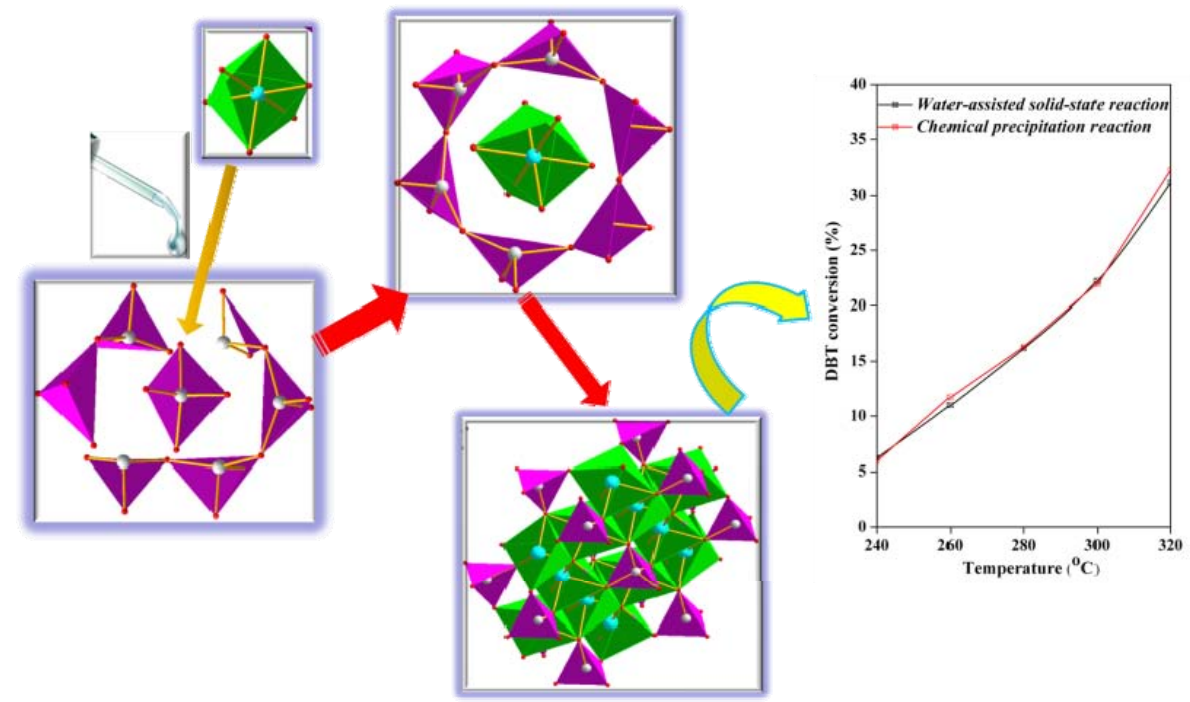

Ammonium nickel molybdate was synthesized, for the first time ever, using a water-assisted, solid-state method. The product exhibits comparable physicochemical and catalytic properties to ammonium nickel molybdate produced by a more traditional chemical precipitation method.

[31] P. Botella, J. M. L. Nieto, B. Solsona, J. Mol. Catal. A, 2002, 184, 335-347.

[32] R. Murugan, H. Chang, J. Chem. Soc., Dalton Trans., 2001, 3125-3132.

[33] I. Pettiti, I. L. Botto, C. I. Cabello, S. Colonna, M. Faticanti, G. Minelli, P. Porta, H. J. Thomas, Appl. Catal. A, 2001, 220, 113-121.

[34] A. Togo, I. Tanaka, K. Murase, T. Yamamoto, T. Suga, E. Matsubara, Mater. Trans., 2004, 45, 1982-1986.

[35] C. Martin, C. Lamonier, M. Fournier, O. Mentré, V. Harlé, D. Guillaume, E. Payen, Inorg. Chem., 2004, 43, 4636-4644.

[36] H. Liu, C. L. Yin, H. Li, B. Liu, X. H. Li, Y. M. Chai, Y. P. Li, C. G. Liu,
Fuel, 2014, 129, 138-146.

[37] D. Levin, S. L. Soled, J. Y. Ying, Chem. Mater., 1996, 8, 836-843.

[38] D. Hasa, G. S. Rauber, D. Voinovich, W. Jones, Angew. Chem. Int. Ed., 2014, 54, 7371-7375.

[39] Z. K. Cao, A. J. Duan, Z. Zhao, J. M. Li, Y. C. Wei, G. Y. Jiang, J. Liu, J. Mater. Chem. A, 2014, 2, 19738-19749.

[40] J. Juan-Juan, M. C. Román-Martínez, M. J. Illán-Gómez, Appl. Catal. A, 2009, 55, 27-32.

[41] H. M. Wang, R. Prins, J. Catal., 2009, 264, 31-43.

[42] W. Q. Fu, L. Zhang, D. F. Wu, M. Xiang, Q. Zhuo, K. Huang, Z. D. Tao, T. D. Tang, J. Catal., 2015, 330, 423-433.

\section{钼酸镍铵的环保合成及其对二苯并噻吩的加氢脱硫反应性能 \\ 刘 欢 ${ }^{\mathrm{a}, \mathrm{b}}$, 殷长龙, 张宏玉 ${ }^{\mathrm{a}}$, 刘晨光 ${ }^{\mathrm{a},{ }^{*}}$ \\ a 中国石油大学 (华东) 重质油国家重点实验室 CNPC 催化重点实验室, 山东青岛 266580 \\ b 中国石化青岛安全工程研究院化学品安全控制国家重点实验室, 山东青岛 266071}

摘要: 日益苛刻的环保法规对柴油中的硫含量提出了更高的要求, 而非负载型加氢脱硫催化剂具有较高的催化反应活性, 其研发及应用不仅具有理论研究价值, 同时还具有较高的社会经济性. 非负载型加氢脱硫催化剂中的典型代表即为 Nebula 催化剂, 该催化剂可以在不更改原有装置的前提下, 使得原始设计生产硫含量为 $500 \mu \mathrm{g} / \mathrm{g}$ 的装置得以生产硫含量不高 于 $10 \mu \mathrm{g} / \mathrm{g}$ 的超低硫柴油. 已有的文献报道中, 非负载型加氢脱硫催化剂前驱体主要是通过水热反应法及化学沉淀法制备 而成. 这两种方法以水为溶剂, 溶剂水的量远远高于反应原料的添加量, 因此, 这两种方法不仅产生大量含有重金属离子 的污水, 同时能量及沉淀剂的消耗较高, 最终导致产品的收率较低, 原子经济性较差. 为了更加环保、可持续地生产非负载 型加氢脱硫催化剂前驱体, 本文报道了一种以加水辅助研磨、固相反应法合成非负载型加氢脱硫催化剂前驱体钿酸镍铵 
$\left(\left(\mathrm{NH}_{4}\right) \mathrm{HNi}_{2}(\mathrm{OH})_{2}\left(\mathrm{MoO}_{4}\right)_{2}\right)$, 并且揭示了其形成机理. 相较于传统的水热反应法和化学沉淀法, 我们提出的固相反应法使合 成过程明显简化, 主要步骤包括原料的物理混合、添加少量水进行研磨及加热. 通过 X 射线衍射、红外光谱及拉曼光谱研 究了钿酸镍铵的形成机理. 结果表明, 在钿酸镍铵的形成过程中, 钿酸铵分子中的一个 Mo 原子被 $\mathrm{Ni}$ 原子取代形成了一种 介稳态中间物种 $\left(\left(\mathrm{NH}_{4}\right)_{4}\left(\mathrm{NiH}_{6} \mathrm{Mo}_{6} \mathrm{O}_{24}\right) \cdot 5 \mathrm{H}_{2} \mathrm{O}\right)$, 而在 $120^{\circ} \mathrm{C}$ 下处理不仅可以移除加入的少量水, 而且促进了钼酸镍铵的形 成. 揭示钿酸镍铵的形成机理对于后续的研究具有重要的意义, 因为可以更有针对性的调节、优化制备方法或者引入其它 溶剂, 从而制备具有某些特定性质的钿酸镍铵类物质. 通过这种固相反应法制备的钼酸镍铵, 具有与化学沉淀法制备的样 品几乎相同的物理化学性质, 包括物相、热稳定性能、孔结构性质等. 不添加任何组分, 将钿酸镍铵前驱体直接压片, 并在 固定床高压微型反应装置中进行原位硫化, 制备了硫化态非负载型加氢脱硫催化剂. 以二苯并噻吩为模型化合物, 考察了 通过化学沉淀法和固相反应法制备的两种钿酸镍铵前驱体的加氢脱硫反应活性. 虽然这两种制备方法有所区别, 但是硫 化态非负载型加氢脱硫催化剂中活性组分二硫化钼 $\left(\mathrm{MoS}_{2}\right)$ 纳米颗粒具有相似的堆积层数和片层长度, 同时对二苯并噻吩 的转化频率 (TOF) 相近, 分别为 $28 \times 10^{-4} \mathrm{~s}$ (固相反应法) 和 $26 \times 10^{-4} \mathrm{~s}$ (化学沉淀法). 因此, 与传统的水热反应法或化学沉 淀法相比, 该法具有简化合成过程、降低水及能源的消耗及提高产品的收率等明显的优势. 对于大规模地合成钿酸镍铵并 用于工业加氢脱硫反应装置中具有重要的意义. 与此同时, 这种少量水辅助研磨固相反应法可以扩展到钼酸镍铵同晶物 质的合成, 例如钼酸钴 (锌、铜) 铵.

关键词: 加氢脱硫; 固相反应法; 加水辅助研磨; 钿酸镍铵; 非负载型催化剂

收稿日期: 2016-03-30. 接受日期: 2016-05-06. 出版日期: 2016-09-05.

*通讯联系人. 电话/传真: (0532)86981716; 电子信箱: cgliu@upc.edu.cn

基金来源：国家自然科学基金 (U1162203, 21106185); 中央高校基本科研业务费 (15CX02023A, 15CX06051A).

本文的英文电子版由Elsevier出版社在ScienceDirect上出版(http://www.sciencedirect.com/science/journal/18722067). 